The Third Pole: Journal of Geography

Vol. 17: 20-36, 2017

Department of Geography Education,

Central Department of Education, T.U., Kathmandu, Nepal

\title{
CHANGING RURAL LIVELIHOOD STRATEGIES IN THE COMMUNITY OF GOLJUNG, RASUWA
}

\author{
Dhyanendra Bahadur Rai ${ }^{1}$
}

\begin{abstract}
Different patterns of livelihood are found in different places within same community or different communities over the generation. Therefore livelihood strategy is a changing process of an individual or a household level of economic and social activities in order to fulfill daily livelihood needs. This paper seeks to explore the changing rural livelihood strategies of a community in mountain region of Nepal. The study is mainly based on primary data collected from field survey, focus group discussion (FGD) and key informant interview (KII). Questionnaire survey was conducted within 52 households by applying random sampling method. Likewise five KII and three FGDs were conducted and participants belonged to different field i.e. ward chairperson, ward women member, businessmen, wage labor, farmer and social worker. The finding indicates that livelihood strategies are changing rapidly in the rural areas. Similarly, multiple sources of income of a household have resulted into secured livelihood system in Goljung. Despite the fact that the agriculture with livestock farming was an important traditional source of livelihood in the past, the roles of non-agricultural sectors have become significant for livelihood sustaining in the rural community in Goljung, Rasuwa in the present days. After a decade, development of the hydro-electricity projects and trade route between Nepal and China has played the catalyst role for changing rural livelihoods of local people in this village.
\end{abstract}

Keywords: Livelihood strategies, household assets, livelihood diversification, Chilime Hydropower, trade route

1 Mr. Rai is an Associate Professor, Central Department of Geography, T.U. Kirtipur, Email:dbrrai@yahoo.com 


\section{Introduction}

Livelihood practice is a survival strategy of an individual or a household. So, it is considered as a continual and changing process of economic and social activities in order to fulfill livelihood needs. A livelihood in its simplest sense is a means of gaining a living. According to Chambers and Conway (1992) "a livelihood comprises the capabilities, assets and activities required for a means of living." The whole plans of actions and activities that undertake individuals or households to overcome or cope with the stress and shocks are known as livelihood strategies. Indeed livelihood strategies are the range and combinations of different activities and choices that individual and group carry out to achieve their livelihood outcomes (DFID, 1999). Ellis (1998) defines the livelihood strategies as the compound activities of household's members undertook their daily livelihoods. The context and content of livelihood strategies can vary in accordance with time and spatial dimension (Paudel, 2003). People use the best strategies among the several alternative choices of the livelihood strategies available in the environment as soon as possible.

Livelihood strategies are ever changing process. The pattern of livelihood strategies of social groups varies on the basis of space and time. Existing socio-cultural values of people in the same space can create differences in the pattern of adaptation from one ethnic group to another. In the same way, adaptation pattern of the same ethnic group may differ from one place to another due to change in the social and physical environment (Subedi and Pandey, 2000). Livelihoods of the rural areas in the world are complex and dynamic in the recent days. Furthermore, global change has further accelerated to this situation. Each and every rural society cannot escape from this situation. A large number of rural livelihoods are directly related to the natural resource at least to some extent (Scooner, 1998). Similarly, most rural households rely on multiple income sources and adopt a wide range of livelihood strategies for food security due to inadequate income from a single occupation (Banskota and Pradhan, 2007). Diversified livelihood systems are less vulnerable compared with undiversified ones (Ellis, 1998). Various non-farm and off-farm activities for earning income are also important in rural areas for secured livelihoods. Rapid and radical transformation in the livelihood system has been appeared in the rural areas of Nepal as the result of infrastructure development i.e. transportation, electricity, communication as well as increasing mobility system (Koirala, 2010; Khatiwada, 2010). Some literature (World Bank Group, 2016) argues that catastrophic disaster also can play as the catalyst role of livelihood strategy in the 
Dhyanendra Bahadur Rai / Changing Rural Livelihood Strategies in the Community of Goljung ...

community. In this context, the paper assesses and analyses the changing livelihood strategies of a rural community, in Goljung, Rasuwa.

\section{The Study Area}

The Goljung village is located from $28^{0} 8^{\prime} 52^{\prime \prime}$ to $28^{0} 10^{\prime} 56^{\prime \prime}$ north latitude and $85^{\circ} 17^{\prime} 14.5^{\prime}$ ' to $85^{\circ} 20^{\prime} 13.5^{\prime}$ 'east longitude. This village is bordered with Syafru to the east and Gatlang to the west and Chilime in the north and Gatlang and Syafru to the south respectively. The physiography occupied by settlement area especially Goljung village is sloppy and it gradually increases steepness to the south. ChilimeKhola (river) flows to the east with deep gorge. The climate type of this area is temperate with average temperature remains in $15^{\circ}$ centigrade. Summer is mild warm and winter is cool in this area. This village was comprised in Goljung VDC in the past and recently, it has been included in Parbatikunda Rural Municipality after restructuring and reorganizing

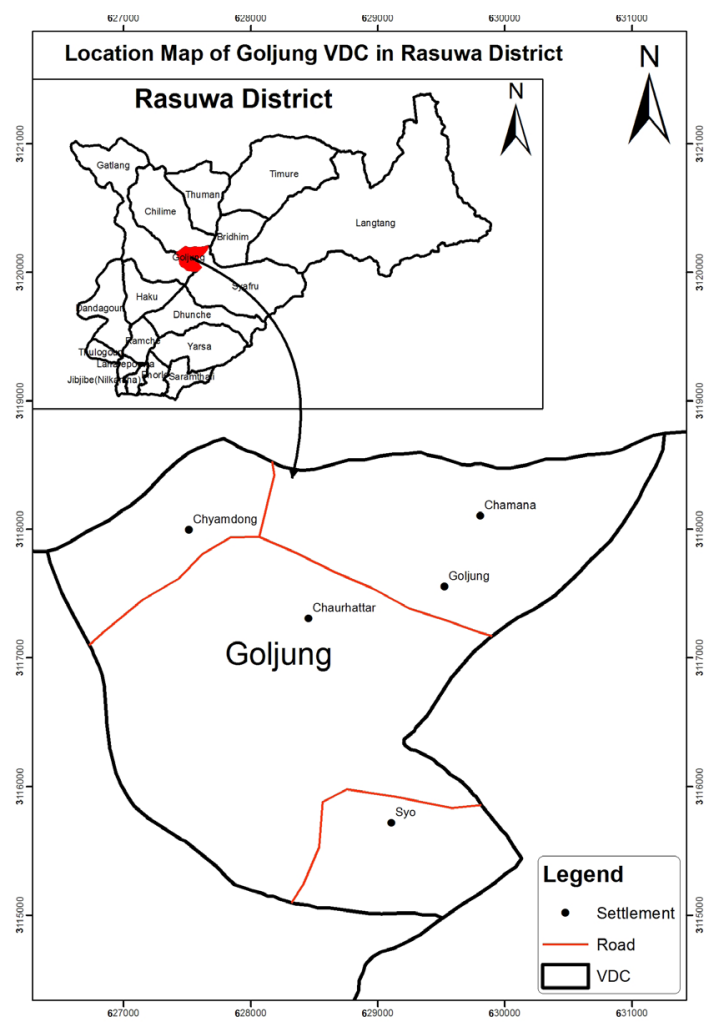
local units in Nepal. Goljung is densely populated village with compact settlement pattern. Tamang is dominant group, covers 86 percent of the total population in Goljung. Rests of the castes are Kshetri, Brahmin, and Dalit. Agriculture with livestock farming is the main traditional occupation of this village. The basic facilities such as school from primary to higher secondary, primary health-post, electricity, communication (mobile service), and drinking water are available in the village within accessible distance.

\section{Methods and Materials}

This study is completely based on primary data collected from the field survey from June 2 to June 12 in 2017. Household survey was conducted applying household questionnaire sheet. Experienced field workers were deployed. Three focus group discussion (FGD) 
and five key informant interview (KII) were carried out by representing different sectors of people i.e. sex, caste/ethnicity, occupation, age and education. There were six to seven persons in each FGD. Long and open interview were taken for key informant interview. An interview guideline was prepared for the purpose of KII. An observation sheet was also used during the field observation so that all tangible phenomena could be recorded by the researcher.

\section{Household Assets and Activities}

Several things are encompassed in the category of household assets. Land is the fundamental assets of a household in the rural context of Nepal because of being a major occupation, agriculture. Not only this, land is considered as the source of power and prestige in the society like Nepal (Pradhan and Pradhan, 2003). Therefore, landless people are rarely found in the rural area of hilly and mountain area of Nepal.

\section{Agriculture and livestock as traditional source of livelihoods}

Agriculture together with livestock rearing is the part and parcel of rural livelihoods in Nepal (Koirala, 2008). It is a common nature of rural economics. Subsistence type of agriculture system is dominant in this category. Basically, there are two types of land i.e. Khet (irrigated rice land) and Bari (un-irrigated terrace land). The land, such as Kharbari, grass land and private forest cover limited area in this area.

Table 1: Status of landholding and ownership in Goljung, Rasuwa

\begin{tabular}{llllll}
\hline Land type & \multicolumn{6}{l}{$\begin{array}{l}\text { Landownedbyhousehold } \\
\text { (Ropani) }\end{array}$} & Household & Percentage \\
& $<3$ & $3-6$ & $>6$ & & \\
\hline Khet & 15 & 20 & 9 & 44 & 84.61 \\
Bari & 14 & 22 & 10 & 46 & 88.46 \\
Khar Bari/grass land & 4 & 6 & - & 10 & 19.23 \\
Private forest & 5 & 6 & - & 11 & 21.15 \\
\hline
\end{tabular}

Source: Field Survey, 2017

Rasuwa is one of the mountainous districts of Nepal. About, 81 percent area of this district is encompassed within 2500-6000 meters altitudinal range (Gurung, 2003). Most of the area of Rasuwa district is covered by steep slope, rugged terrain and stony surface. So, low productivity as well as thin layer of top soil is common character of 
Dhyanendra Bahadur Rai / Changing Rural Livelihood Strategies in the Community of Goljung ...

farmland in this area. Small land holding size is common phenomena in Goljung due to limited agricultural land available in whole Rasuwa district. Certain area of the district is suitable for agriculture and human habitation. Goljung is also an example of it. In the total household, about 88 percent have Bari whereas nearly 85 percent have Khet. Similarly, limited people have Khar Bari/grass land (19.23 percent) and private forest (21.15 percent). A large number of owners constitute in the category of 3-6 Ropanies of land. The owning size of land is decreasing day by day because of fragmentation of land within family. There is dominant position of food crops i.e. rice, maize, wheat, millet etc. Potato and lentil are grown as cash crops in the winter season. Black lentil, grown in this village is popular for Daal.Household food sufficiency from own production is decreasing continuously. Gradually, the dependency upon self-production from agriculture has been changed. Negligence towards agricultural activities in the village has increased. Agriculture has become only a formal activity of the people. As the result, the fallow land in Goljung has increased. Most of the consumable goods are supplied from road transport all the year. There occurred starvation as common phenomena in the past because of crop damaging by drought, hailstone and wind.

Livestock farming is also an indispensible part of agriculture all over the rural areas of Nepal. So, it is considered as the complementary part of Nepalese economy. Furthermore, this practice is more widespread in the mountain region of Nepal. Cattle are reared in the upper part for the purpose of dairy products, means of plowing as well as compost manure. In the case of Goljung, cattle are outnumbered than other livestock. Most of the household keep cattle for domestic purpose. Some household who have in large number, they keep their cattle in Kharka for the purpose of cash income by selling Chhurpi, cheese and ghee. Chhurpi, produced in Goljung, Chilime and Gatlang is transported in Kathmandu. Ox is also known as the source of cash income in these days because one pair of oxen with labor earns 2000 rupees per day from rent. The households who do not keep ox, they have to use oxen for agriculture in rent. The main purpose of rearing buffalo is for milk and manure. Gradually, cattle and buffalo both are decreasing day by day in Goljung due to the shrinkage of grazing land, losing of grass as well as shortage of manpower. 
The Third Pole: Journal of Geography, Volume 17, 2017

Table 2: Livestock assets in Goljung, Rasuwa

\begin{tabular}{|c|c|c|c|c|c|}
\hline Animal & $\begin{array}{l}\text { Total } \\
\text { number }\end{array}$ & $\begin{array}{l}\text { Total value } \\
\text { if sold }\end{array}$ & $\begin{array}{l}\text { Annual } \\
\text { income }\end{array}$ & $\begin{array}{l}\text { Trend for } \\
\text { past ten } \\
\text { years }\end{array}$ & Reason for change \\
\hline Cow & 98 & 30,000 & 150,000 & decreased & $\begin{array}{l}\text { Decrease in grazing } \\
\text { land, grass and } \\
\text { manpower shortage in } \\
\text { the village }\end{array}$ \\
\hline Ox & 60 & 15,000 & 85,000 & Decreased & $\begin{array}{l}\text { Low priority to } \\
\text { farming }\end{array}$ \\
\hline Buffalo & 25 & 40,000 & 145,000 & Decreased & $\begin{array}{l}\text { Decrease in grazing } \\
\text { land and grass as well } \\
\text { as manpower }\end{array}$ \\
\hline $\begin{array}{l}\text { Goats/ } \\
\text { sheep }\end{array}$ & 158 & 12,000 & 450,000 & $\begin{array}{l}\text { Slightly } \\
\text { decreased }\end{array}$ & $\begin{array}{l}\text { Shrinkage in grazing } \\
\text { land and manpower }\end{array}$ \\
\hline $\begin{array}{l}\text { Chicken/ } \\
\text { ducks }\end{array}$ & 208 & 10,000 & 60,000 & Increased & $\begin{array}{l}\text { Poultry farming } \\
\text { emerged as good source } \\
\text { of cash income }\end{array}$ \\
\hline Pig & 48 & 12,000 & 120,000 & Decreased & $\begin{array}{l}\text { Feeding problem due } \\
\text { to decrease in grain } \\
\text { production }\end{array}$ \\
\hline
\end{tabular}

Source: Field Survey, 2017

Comparatively, the practice of goat farming has not so decreased like buffalo and cattle. It has become an important source of cash income. Goat farming is easy because it doesn't need heavy grass land and full time manpower for keeping. Extent of enough grazing land for goat has increased as the result of fallow land. Demand of mutton is also high from village to urban area in Nepal. So, the price is also attractive. Middlemen carry several goats from this area to Dhunche, Trisuli and Kathmandu in different season, especially during Dashain-Tihar. The practice of keeping fowls in this area has increased due to the beginning of poultry farming in spite of small scale in the village. There is no lack of market for production. The tendency of meat consumption has excessively increased in the village. In the same way, purchasing power in the rural area has also increased. Pig is also decreasing due to the problem of feeding because it needs grain for feed. Usually, maize is used for the best feed but its local production has been decreasing. 
Dhyanendra Bahadur Rai / Changing Rural Livelihood Strategies in the Community of Goljung ...

The usage of same thing is varied with the time and space. Use of needy goods may be changed into luxurious goods and vice versa. Such kinds of change come into existent as the result of changing pattern of livelihood in the community according to time and space. As indicated by table, most of the assets of the household are more common than before ten years. The things such as laptop/computer, cable network, motorcycle, cylinder gas, rice cooker etc. were new and recent things at that time. Most of the goods listed in the table were luxurious for the inhabitant of Goljung. But today, most of them are goods of necessity. Rice cooker, cylinder gas and refrigerator have become needy goods because of growing income level of people in the village. Similarly, inaccessibility of firewood has also decreased. Modern science and technologies have become as essential things to mobile, TV, and cable/disk. Similarly, modern education has made laptop and computer as useful things.

Table 3: Household Assets in Goljung, Rasuwa

\begin{tabular}{|c|c|c|c|}
\hline $\begin{array}{l}\text { Household } \\
\text { Assets }\end{array}$ & $\begin{array}{l}\text { Household } \\
\text { assets (\%) }\end{array}$ & $\begin{array}{l}\text { Before ten } \\
\text { years }(\%)\end{array}$ & Reasons for change \\
\hline Radio & 10 & 70 & $\begin{array}{l}\text { Several options of radio like mobile, TV } \\
\text { etc. }\end{array}$ \\
\hline $\mathrm{TV}$ & 60 & 8 & $\begin{array}{l}\text { Adopted as main source of entertainment } \\
\text { and communication }\end{array}$ \\
\hline Laptop & 8 & 0.5 & Using as the means of educational tools \\
\hline Cable/disk & 10 & 2 & Increased source of cash income in village \\
\hline Mobile & 100 & 10 & Using as fashion and man became habitual \\
\hline Refrigerator & 4 & 0.5 & $\begin{array}{l}\text { Source of cash income increased within the } \\
\text { decade }\end{array}$ \\
\hline Cylinder gas & 50 & 1 & $\begin{array}{l}\text { Increasing income source lead to people to } \\
\text { luxurious life }\end{array}$ \\
\hline Rice cooker & 25 & 2 & Availability of electricity network \\
\hline Motorcycle & 7 & 1 & $\begin{array}{l}\text { Immediately income increased due to } \\
\text { hydro }\end{array}$ \\
\hline Tractor/truck & 5 & - & $\begin{array}{l}\text { Established as transporting enterprising } \\
\text { activities }\end{array}$ \\
\hline $\begin{array}{l}\text { Agriculture } \\
\text { implements }\end{array}$ & 98 & 78 & Shifting towards non-agricultural sector \\
\hline
\end{tabular}

Source: Field Survey, 2017 
Before ten years, radio was a common thing for entertainment and communication in the rural area, no alternative of it. However, various means of communication and entertainment such as TV, mobile phone have replaced it. Different brand of mobilesets are used in the village which are used multi purposely for video, audio, camera and so on. Fashion of mobile has become more widespread in the rural areas in the recent days. Some households have established entrepreneurship related with truck and tractor when construction of hydro-electricity project began. They supply construction materials such as sand, stone, bricks, aggregate, iron rods and cement as petty contractor for projects. Material supplies for projects and petty contract in the projects as well as other development works have become an important source of employment and income of the people in Goljung. Users of motorcycle have increased when volume of cash flow increased in the village for the compensation of land by different hydro powers, increasing share value of Chilime Hydropower and Gorkha Earthquake. Nowadays, some households of Goljung, Chilime and Syafru village have share of Chilime Hydropower equivalent to forty to fifty lakhs. The situation of agriculture has notably changed between these ten or fifteen years. Gradually, interest towards agriculture has been decreasing. Fallow land is increasing and intensive farming is decreasing. Some households have shifted from their main occupation, agriculture to business, petty contactor as well as wage labor.

\section{Household Income and Expenditure}

There are various sources of household income in Goljung village. Despite the fact that agriculture is a traditional occupation as well as important source of livelihood, it is not the main source of cash income because of self-consumption of produced crops. The income from agriculture has been going to decrease day by day. Remittance accounts top most source of income in this village followed by salaried job. Basically, some people have got technical sector like engineer and overseer and others have got normal job like driver, security and administrative personnel in hydropower. Similarly, petty business has also become attractive sector of the people for earning livelihood caused by hydro project in these days. 
Dhyanendra Bahadur Rai / Changing Rural Livelihood Strategies in the Community of Goljung ...

Table 4: Household Income in Goljung, Rasuwa

\begin{tabular}{|c|c|c|c|}
\hline Sources & $\begin{array}{l}\text { Last year } \\
\text { income }\end{array}$ & $\begin{array}{l}\text { Trend of last } \\
\text { ten years }\end{array}$ & Reasons for change \\
\hline $\begin{array}{l}\text { Agriculture } \\
\text { products }\end{array}$ & $3,85,784$ & Decreased & $\begin{array}{l}\text { Negligence or low priority to } \\
\text { agriculture }\end{array}$ \\
\hline $\begin{array}{l}\text { Livestock } \\
\text { products }\end{array}$ & $5,00,000$ & Decreased & $\begin{array}{l}\text { Declining in quantity and quality of } \\
\text { livestock }\end{array}$ \\
\hline Livestock sell & $8,00,000$ & Decreased & $\begin{array}{l}\text { Declining in quantity and quality of } \\
\text { livestock }\end{array}$ \\
\hline Wage labor & $10,50,000$ & Increased & $\begin{array}{l}\text { Increasing opportunity in } \\
\text { construction including hydro and } \\
\text { increased in wage rate }\end{array}$ \\
\hline Petty business & $12,00,000$ & Increased & $\begin{array}{l}\text { Petty business emerged as the } \\
\text { source of cash income after hydro } \\
\text { project }\end{array}$ \\
\hline $\begin{array}{l}\text { Remittance and } \\
\text { pension }\end{array}$ & $16,50,000$ & Increased & $\begin{array}{l}\text { Increasing trend of foreign } \\
\text { employment }\end{array}$ \\
\hline Salaried job & $16,00,000$ & Increased & $\begin{array}{l}\text { Getting opportunity salaried job in } \\
\text { hydro }\end{array}$ \\
\hline NTFP sell & $2,50,000$ & Increased & Value of NTFP has increased \\
\hline Others & $12,00,000$ & Increased & Diversified income sources \\
\hline
\end{tabular}

Source: Field Survey, 2017

The traditional sources of income such as related with agriculture and livestock have decreased, but all the other sources have increased. In fact, local people are not excited for agriculture. However, they are involved in agricultural work as their traditional occupation as customary but not profit motive. Basically, new sources of income emerged in non-agricultural sector in the local area as well as outside and abroad including. Off-farm income generating activities are uprising. The role of hydro-electricity project is significant in this matter. In the same way, Chilime Share also has played an important role in the livelihood pattern of Goljung inhabitant. Not only Chilime Hydro Electricity Project, other newly under construction (Sanjen and Upper Sanjen) has provided important sources of various opportunities for the inhabitants of this area. Opportunity of wage labor for local people is prime sector of earning livelihood. Due to those construction works, the wage rate of labor is increasing which is truly beneficial to Goljung people. 
Self-dependency from own production has been decreasing over in Goljung. All the goods related with agriculture and non-agriculture have to purchase for self-consumption. The amount, equal to NPR 2.5 million is spent for house repairing followed by food items in the sampled household. The total expenditure amount of house repairing is excessively high. Most of the houses had been damaged and destroyed by Gorkha Earthquake in 2015. Hence, the expenditure of house repairing is so high in this period. Several children of Goljung village study in the school of Kathmandu living in boarding house. Some parents who are financially capable are interested for better education. Awareness towards education has increased. Investment in education especially private boarding school has increased. According to FGD, conducted in Goljung, one child spends about 1 lakh annually in Kathmandu. In the village, no more money is needed for children education. Taking this view in mind, the people of this village are more excited for providing quality education to their descendants.

Table 5: Household Expenditure in Goljung, Rasuwa

\begin{tabular}{|c|c|c|c|}
\hline Expenditure items & Total expense & $\begin{array}{l}\text { Trend for past ten } \\
\text { years }\end{array}$ & Reason for change \\
\hline Food items & $15,40,000$ & Increased & $\begin{array}{l}\text { Declining in production for } \\
\text { self-consumption }\end{array}$ \\
\hline Education & $12,12,000$ & Increased & $\begin{array}{l}\text { People send their children out } \\
\text { of village for school education }\end{array}$ \\
\hline Health care & $5,50,000$ & Increased & Expensive health facilities \\
\hline Clothing & $3,50,000$ & Increased & Extension in fashion \\
\hline Festival/social events & $5,20,000$ & Increased & Extravagant tendency \\
\hline $\begin{array}{l}\text { Travel and } \\
\text { communication }\end{array}$ & $3,00,000$ & Increased & $\begin{array}{l}\text { High mobility and increasing } \\
\text { trend of cell phone }\end{array}$ \\
\hline House repairing & $25,00,000$ & Increased & $\begin{array}{l}\text { Catastrophic } \\
\text { damaged house }\end{array}$ \\
\hline Agricultural activities & $7,50,000$ & Constant & Subsistence type of agriculture \\
\hline Others & $5,40,000$ & & \\
\hline
\end{tabular}

Source: Field Survey, 2017

Imitation of fashion has also increased in the amount of expenditure especially in clothing. Due to increasing mobility and means of communication, imitation has increased in the remote rural areas which are reflected in the daily fashion of young boys and ladies. Extravagant tendencies have been increased in the social events. Expensive health facilities have created more amount of expenditure in the health sector. Increasing trend || $30 \|$ 
Dhyanendra Bahadur Rai / Changing Rural Livelihood Strategies in the Community of Goljung ...

of mobility within the village and beyond as well as means of communication especially mobile service has increased expenditure. The expenditure, belonged to agriculture is about the same during the past ten years. The system and method of agriculture is subsistence as before which needs no more investment. Parma system is also common from very beginning in this area. It is easy and accessible because of agglomerated settlement and about single community in a village. This system is still popular in the village. It requires no money for laboring but exchange labor among each other within community. Furthermore, it has become essential because of lacking agricultural manpower in those days. If not so, farming is impossible in the village. Major agricultural works such as planting, weeding and harvesting are completed with this system because those items require more manpower. After completing major works of farming, usually male member of the household can leavetheir houses for cash earning.

\section{Livelihood Diversification: Emergence of New Sector of Income Source}

Mainly, diversification of livelihood, in the recent days, is caused by access of road, market expansion and access of power in the case of Nepalese rural areas. Those things open new opportunities for employment and sources of income for the local people. Diversified income sources lead to the multiple sources of income. Multiple income sources are more secured than single one in any situation (Chambers and Conway, 1992). Basically, transformations of on-farm activities to off-farm activities are appeared in the rural areas as new source of income. A good example of this is found easily in the context of Goljung, community in Rasuwa. Reflection on changing lifestyle and livelihood strategies of the communities in the recent days also indicates this situation.

Table 6: Occupational status in Goljung, Rasuwa

\begin{tabular}{lll}
\hline Primary occupation & Population & Percentage \\
\hline Farming & 192 & 22.88 \\
Household works & 120 & 14.30 \\
Petty business & 75 & 8.94 \\
Salaried job & 15 & 1.78 \\
Student & 188 & 22.41 \\
Wage labor & 215 & 25.63 \\
Foreign employment & 16 & 1.91 \\
Other & 18 & 2.15 \\
\hline Total & 839 & \\
\hline
\end{tabular}

Source: Field Survey, 2017 
In the decade of $1950 \mathrm{~s}$, agriculture with livestock farming was the solely dominant occupation of Goljung as reported by key informants. There was no alternative of agriculture as the source of livelihood in Goljung. Today, the situation has been changed. About 26 percent people of Goljung are engaged in wage labor whereas agriculture accounts nearly 23 percent in the recent days. Similarly, about 9 percent people are involved in petty business. Groceries, catering, local liquor production, vending, poultry farming, knitting clothes etc. are some of the example of petty business in this area. Studies carried out by Khatiwada (2010) and Rajbansi (2010) in the other areas of country such as Tankhuwa, nearby Dhankuta bazar and peri-urban area of Kathmandu also indicate that ethnic community like Tamang, Newar and Magar are involved in production of local liquor as the important source of income. Liquor is known as necessary thing to the socio-cultural point of view in those communities. So, production and consumption of liquor is a common activity of a household. However, in those days, household produced local liquor (beer and alcohol) for cash income not only for domestic use. Some households have adopted it as a small enterprise. They produce local alcohol as the demand of local market. Due to the establishment of small market centers, the demand of local liquor has increased excessively. There is rarely found a catering shop without keeping alcoholic goods in the market center. So, it has become an important source of cash income of the people in the village.

The issue of cultural identity in Nepal has become widespread. Wearing traditional clothes in cultural programs has become common. So, the demand of cultural dresses is increasing from rural to urban areas in Tamang community. That is why, Knitting traditional clothes related with Tamang community such as Syade (round cap), Angdun (Sari) and Panghap (the dress wrapped under waist by women) has been popular cottage industry as the source of cash income in this area. This type of industry has helped for conservation of culture and tradition of Tamang community. Such materials are supplied to Kathmandu and other parts of Nepal. Usually, women are involved in this cottage industry. Self-employment has been created by the help of such enterprises.

Other important sources of income are foreign employment, salaried job in hydroelectricity project, government job as well as the job at NGOs in the village. As the important physical capital, water resource has brought radical change in the life of whole Rasuwa people. Furthermore, some villages i.e. Chilime, Goljung, Syafru, Timure, Haku, and, Dhunche have got more benefit from hydropower. Chilime, Goljung and Syafru have special privilege for getting IPO (initial public offering) share of Chilime 
Dhyanendra Bahadur Rai / Changing Rural Livelihood Strategies in the Community of Goljung ...

Hydropower. Chilime is considered as a successful project developed by NEA (Nepal Electricity Authority) in its own technology and investment. So, this hydropower has become a role model in Nepal. All the households of these three villages have got Chilime share. According to an engineer of Chilime Hydropower, one household of the village has share equal to forty lakhs rupees. In this connection, he further states that;

Almost all the households have got Chilime Hydropower share of these three villages i. e. Chilime, Goljung and Syafru. The role of K. M. Ghising is great for providing share who was head of this project at that time. So, people of this area respect him as God. Project provided share to people by reaching home to home as well as reaching jungle and cave while they resided there with their cattle at summer season. We provided share by giving name Share Kumar/Share Kumari who were newly born during that moment.

Increasing value of Chilime provided more benefit to the people of three VDCs. The value of one share (100 rupee's share) reached up to NPR 2700 before ten years. After attraction of Chilime share, wealthy people captured common people's share overnight. Middlemen are active for capturing share in the village. People from outside Rasuwa are entering there for the purpose of getting share by purchasing land since there is a provision of being land holder for getting IPO. Two under-construction hydropower (Sanjen and Upper Sanjen) nearby this village which are related with Chilime Hydropower will provide IPO to the people of Goljung in the near future for their high benefit. The villagers sell their share in case of extreme scarcity of money.

Malaysia and Gulf countries are main destination of the people especially young. Most of the remittances, obtained from foreign employment are used for the purpose of purchasing ghaderi (homestead), construction home as well as fulfilling daily domestic needs. Limited remittance is used in the productive sector. Very few women are belonged to foreign employment. Generally, women are still involved in household works. Thus, the household adopting diverse activities for earning livelihoods may represent secure and sustainable livelihoods in the recent days in this area. A study conducted by Rijal (2006) in Modi Watershed area also reveals this situation.

Substantial changes in the livelihood of people living in this area came after opening of Rasuwagadhi-Kerung as the main trade route between Nepal and China when the Tatopani-Khasha trade route damaged by Gorkha Eartquake in 2015. Various 
opportunities are opened for Rasuwa residents since then. The people living nearby highway got direct benefit from this event. Goljung also falls in this category. Gradually, people are coming to market center located in the highway for searching different opportunities from portering to business purpose. A large number of young people are engaged in Timure dry-port for load and unload works in the container. According to the information of a porter, one porter earns nearly two thousand to three thousand rupees in a day in the season. Some people from Goljung have gone to Syafru, Timure and Dhunche for the purpose of business. After opening the highway as a major trade route, the business especially hotel-lodge, catering, groceries etc. have been increasing significantly. Most of the youths of this district have got enough chance for driving container to Kerung because there is no permission entering China except Rasuwa people. So, almost all businessmen must change their container driver from check post in Rasuwagadhi. As a result, the driver residents of Rasuwa who have driving license of heavy vehicle earn a lot of money. Hence, young people of this area are attracted towards driving sector. Some people have invested money in the transport sector by purchasing container and trucks for supplying goods from Kerung to Kathmandu. Such kinds of formal and informal activities carried out in the area of trade route creates various types of cash earning opportunities which may result the society be money oriented.

\section{Conclusion}

Livelihood strategy is a way of living a gaining. It differs as per community as well as changes over space and time. Changing livelihood strategies in Goljung village of Rasuwa, a dominant territory of Tamang community, have been markedly changing over the decade. In the past, there was only one basic source i.e. agriculture with livestock farming for livelihood sustaining in this area like other parts of Nepal. Now, people of Goljung are not dependent solely on one occupation for their livelihood supporting. Multiple sources of household income have appeared in Goljung which have led to diversification on livelihoods in this area. Diversified income source is the foundation of secure and sustainable livelihood. Gradually, the roles of non-farm activities for sustaining livelihoods are increasing apparently day by day. Shifting from subsistence agriculture to non-agricultural activities concerning cash earning has become common phenomena in this area. Petty business, wage laboring, foreign labor migration, small enterprises are some of the important off-farm sources of income in Goljung, Rasuwa. Basically, Chilime Hydropower, other under-construction hydro powers and trade route between Nepal and China have played catalyst role for changing livelihood strategies in the community of Goljung, Rasuwa. 
Dhyanendra Bahadur Rai / Changing Rural Livelihood Strategies in the Community of Goljung ...

\section{References}

Banskota, S. and Pradhan, P. K. (2007).Non-timber forest product-based livelihoods of the rural communities in the SheyPhoksundo National Park,Nepal.Nepalese Journal of Development and Rural Studies. 4, No 1:71-82.

Chambers, R. and Conway, G. R. (1992).Sustainable Rural Livelihoods: Practical Concepts for the $21^{\text {st }}$ Century. Institute of Development Studies.

DFID (1999).Sustainable livelihoods guidance sheet. London: Department for International Development (DFID).

Ellis, F. (1998).Livelihood diversification and sustainable rural livelihoods. In: D. Carney (ed). Sustainable Rural Livelihoods: What contribution can we make? London: Department for International Development.

Gurung, H. (2003). Patterns of elevation range in Nepal. The Himalayan Review, Vol. XXXVIV, 17-32.

Khatiwada, S. P. (2010). Continuity and change of livelihood activities in the TankhuwaKhola Watershed in Eastern Hills, Nepal. In: P. K. Pradhan, B. P. Subedi and N. R. Khanal (Eds.), Environmental, Livelihood and MicroEnterprises. Kathmandu: Central Department of Geography: Tribhuvan University, Nepal.

Koirala, H. L. (2010). Changing livelihood strategies in the hills and mountains: Experiences of eastern Nepal. In: P. K. Pradhan, B. P. Subedi and N. R. Khanal (Eds.), Environment, Livelihood and Micro-Enterprises. Kathmandu: Central Department of Geography: Tribhuvan University, Nepal.

Poudel, K. P. (2003). Resources and livelihood in the Chepangs' Community, Nepal.The Himalayan Review, Vol. XXXIV, 33-51.

Pradhan, P. K. and Pradhan, B. (2006).Environment and Natural Resources: Concept, Methods, Planning and Management, Kathmandu: Quest Publication Kirtipur. Nepal.

Rajbansi, A. (2010). Livelihood diversification in a periurban area of Nepal: A survival strategy of marginal communities. In: P. K. Pradhan, B. P. Subedi and N. R. Khanal (eds), Environmental, Livelihood and Micro-Enterprises. Kathmandu: Central Department of Geography: Tribhuvan University, Nepal. 
Rijal, S. P. (2006). Livelihood strategies and income level of people of Modi Watershed, Nepal. The Himalayan Review, Vol. XXXVII, 19-37.

Scoones, I. (1998), Sustainable rural livelihoods: A framework for analysis (IDS Working Paper 72), Institute of Development.

World Bank Group (2016). Migration and remittances: Recent developments and outlook.International Bank for Reconstruction and Development / The World Bank 1818 H Street NW, Washington DC 20433 